\title{
SKRINING FITOKIMIA DAN UJI AKTIVITAS ANTIOKSIDAN DARI EKSTRAK ETANOL BIJI KOPI ARABIKA (Coffea arabica) YANG TUMBUH DI DAERAH GAYO DENGAN METODE DPPH
}

\author{
Nasirah Maulidia Ajhar*, Debi Meilani \\ Fakultas Farmasi, Universitas Muslim Nusantara Alwasliyah, Medan \\ *Penulis korespondensi: lidiaajhar@gmail.com
}

\begin{abstract}
ABSTRAK
Buah kopi termasuk buah musiman yang hanya muncul pada bulan bulan tertentu. Di daerah Gayo kopi merupakan minuman yang hampir setiap hari di konsumsi. Kopi diduga mempunyai aktivitas antioksidan sehingga mampu merendam aktivitas radikal bebas. Tujuan dari penelitian ini melakukan skrining fitokimia dan mengetahui aktivitas antioksidan dari ekstrak etanol biji kopi arabika dengan metoda 2,2-Diphenyl-2picrylhydrazyl (DPPH). Ekstrak biji kopi arabika di buat dengan cara perkolasi dengan menggunakan pelarut etanol dan ekstrak yang diperoleh di pekatkan menggunakan rotary evaporator, selanjutnya ekstrak etanol di uji kekuatan aktifitas antioksidannya dengan menggunakan metoda 2,2-Diphenyl-2-picrylhydrazyl (DPPH) pada panjang gelombang maksimum $516 \mathrm{~nm}$, sebagai kontrol positif digunakan vitamin C. Hasil skrining fitokimia menunjukkan bahwa ekstrak etanol biji kopi arabika mengandung golongan senyawa tanin, alkaloid, saponin, flavonoid, dan steroid. Hasil penelitian menunjukkan aktivitas antioksidan ekstrak etanol biji kopi arabika termasuk kategori sangat kuat dengan $\mathrm{IC}_{50} 12,427$ ppm dan vitamin $\mathrm{C}$ dengan $\mathrm{IC}_{50}$ 0,273 ppm.

Kata kunci : Skrining Fitokimia, Antioksidan, Ekstrak Biji Kopi Arabika, DPPH.

\section{PHYTOCHEMICALS SCREENING AND ANTIOXIDANT ACTIVITY FROM ARABICA COFFEE (Coffea arabica) ETHANOL EXTRACT WHICH GROW IN GAYO AREA WITH DPPH METHOD}

\begin{abstract}
Coffee seasonal fruit that only appears in certain months. In the Gayo area, coffee is a beverage which was is consumed almost every day. Coffee allergrdly has antioxidant activity that can can immerse free radical activity. This study aimed to screen phytochemicals and determine the antioxidant activity of ethanol extracts of Arabica coffee beans using the DPPH method. Arabica coffee beans extract was made by percolation using ethanol solvent and the extract obtained is concentrated using a rotary evaporator, then it was is tested for its antioxidant activity strength by using the 2,2-Diphenyl-2-picrylhydrazyl (DPPH) method at a maximum wavelength of $516 \mathrm{~nm}$, as a positive control was used vitamin C. Phytochemical screening results indicated that the ethanol extract of Arabica coffee beans contains a group of tannins, alkaloids, saponins, flavonoids, and steroids. The results showed the antioxidant activity of Arabica coffee bean ethanol was very strong with category with IC 5012.427 ppm and vitamin C with IC50 0.273 ppm.
\end{abstract}

Keywords: Phytochemical Screening, Antioxidants, Arabica Coffee Bean Extract, DPPH. 


\section{PENDAHULUAN}

Antioksidan adalah senyawa yang mempunyai struktur molekul yang dapat memberikan elektronnya kepada molekul radikal bebas dan dapat memutus reaksi berantai dari radikal bebas (Kumalaningsih, 2006). Tubuh memiliki mekanisme pertahanan antioksidan dalam bentuk enzim antioksidan dan zat antioksidan untuk menetralisir radikal bebas, tetapi karena perkembangan industri yang pesat, manusia berkontak dengan berbagai sumber radikal bebas yang berasal dari lingkungan dan dari kegiatan fisik yang tinggi sehingga sistem pertahanan antioksidan dalam tubuh tidak memadai (Silalahi, 2006). Antioksidan merupakan sustansi nutrisi maupun non-nutrisi yang terkandung dalam bahan pangan, yang mampu mencegah atau memperlambat terjadinya proses oksidasi (Tamat et al., 2007; Winarsi, 2007). Antioksidan sangat bermanfaat bagi kesehatan dan kosmetik serta berperan penting dalam mempertahankan mutu produk pangan (Tamat et al., 2007).

Kopi merupakan salah satu hasil perkebunan yang memiliki nilai ekonomis yang cukup tinggi di antar tanaman perkebunan lainnya dan berpera penting sebagai sember devisa Negara. Salah satu produksi kopi yang cukup terkenal di Provinsi Aceh berada di Kabupaten Aceh Tengah, kopi asal Aceh Tengah terkenal dengan Kopi Gayo. Kopi merupakan tanaman yang banyak ditemukan pada beberapa negara dibelahan dunia dan telah dikonsumsi sebagai minuman. Negara maju dan berkembang tidak ingin ketingalan untuk mengkonsumsi kopi. Kopi paling sering beredar dipasaran berasal dari biji kopi robusta (Coffea canephora) dan biji kopi arabika (Coffea arabica) (Hanindyo, 2014)

Berdasarkan uraian di atas, maka penulis tertarik untuk meneliti antioksidan ekstrak etanol biji kopi arabika yang tumbuh di daerah gayo dengan metode 2,2-Diphenyl-2picrylhydrazyl (DPPH), karna di daerah gayo hampir semua masyarakatnya setiap harinya menggonsumsi kopi.

\section{BAHAN DAN METODE}

\section{Desain Penelitian}

Metode penelitian yang dilakukan adalah penelitian deskriptif atau non eksperimental, karena tidak ada subjek uji yang dimanipulasi atau dikenai kontrol. Penelitian ini dilakukan meliputi pengumpulan bahan, pembuatan ekstrak etanol, skrining fitokimia dan uji aktivitas antioksidan dengan metode DPPH dengan menggunakan alat spektrofotometer visibel. 


\section{Alat}

Alat-alat yang digunakan terdiri dari: alat-alat gelas, cawan penguap, penangas air (waterbath), neraca kasar, neraca listrik, seperangkat alat rotary evaporator (Eyela) dan spektofotometer UV-Vis (Shimadzu UV-1700).

\section{Bahan}

Bahan yang digunakan dalam penelitian ini adalah biji kopi arabika segar berwarna merah. Bahan-bahan kimia lainnya adalah: 2,2-diphenyl-2picrylhydrazyl (DPPH), vitamin $\mathrm{C}$, etanol, metanol, isopropanol, eter, asam nitrat, $\alpha$-naftol, asam sulfat, benzen, asam asetat anhidrat,natrium hidroksida, asam klorida pekat, iodium, raksa (II) klorida, timbal (II) asetat, besi (III) klorida, kloralhidrat, bismut (III) nitrat, kalium iodida, amil alkohol, arang aktif dan serbuk $\mathrm{Mg}$.

\section{Prosedur Penelitian}

\section{Identifikasi Sampel}

Identifikasi sampel dilakukan di HERBARIUM MEDANESE (MEDA) Fakultas Matematika dan Ilmu Pengetahuan Alam Universitas Sumatera Utara.

\section{Pengolahan Sampel}

Bahan baku biji kopi arabika yang masih segar dikumpulkan, di bersih dari kotoran, di kupas biji kopi dari kulit kopi dan ditimbang beratnya $1 \mathrm{~kg}$. Kemudian biji kopi arabika di belender hingga halus, dan kemudian di timbang 500 gram dan di masukkan ke wadah.

\section{Pembuatan Ekstrak Etanol Biji Kopi Arabika}

Sebanyak 500 g biji kopi arabika dimasukan ke dalam perkolator, di tambahkan etanol 99,9\% secukupnya hingga terendam dan terdapat cairan penyari di atasnya, percolator di tutup dengan aluminium foil dan di biarkan selama 24 jam. Kran percolator di buka dan di biarkan cairan ekstrak menetes dengan kecepatan 20 tetes permenit dan di tambah etanol 99,9\% berulang ulang secukupnya dan di atur kecepatan penetesan cairan penyaring sama dengan kecepatan tetesan perkolat, sehingga selalu terdapat selapis cairan penyaringan di atas simpisia. Perkolasi di hentikan jika hasil perkolat tidak berwarna lagi (larutan bening). Perkolat kemudian di uapkan dengan tekanan rendah pada suhu tidak lebih dari $50^{\circ} \mathrm{C}$ menggunakan alat rotary evaporator sampai di peroleh ekstrak kental dari biji kopi arabika (Depkes, 1995). 


\section{Skrining Fitokimia}

Skrining fitokimia meliputi pemeriksaan golongan senyawa alkaloida, flavonoid, saponin, tanin, glikosida, glikosida antrakuinon dan steroida.

\section{Pengukuran Absorbansi DPPH Setelah Penambahan Sampel}

Larutan sampel dipipet $0,5 \mathrm{ml} ; 1 \mathrm{ml} ; 1,5 \mathrm{ml} ; 2 \mathrm{ml}$, kemudian masing masing dimasukkan ke dalam labu tentukur $25 \mathrm{ml}$ (untuk mendapatkan konsentarsi larutan uji 20 ppm, 40 ppm, 60 ppm, dan 80 ppm ). kedalam masing masing labu tentukur ditambahkan 5 ml larutan DPPH 0,5 mM (konsentrasi $40 \mathrm{ppm}$ ) lalu volumenya dicukupkan dengan methanol sampai garis tanda kemudian di diamkan di tempat gelap selama 9 menit. Pengukuran dilakukan sebanyak 3 kali.

\section{Pengukuran Absorbansi DPPH Setelah Penambahan Vitamin C}

Ditimbang sebanyak $50 \mathrm{mg}$ vitamin C Kristal kemudian dilarutkan dengan metanol dalam labu tentukur $50 \mathrm{ml}$. Volumenya dicukupkan dengan metanol sampai garis tanda (konsetrasi 1000 ppm). Kemudian dipipet 0,5 ml; dimasukkan ke dalam labu tentukur $50 \mathrm{ml}$ volumenya dicukupkan dengan methanol sampai garis tanda (konsentrasi $10 \mathrm{ppm}$ ). Kemudian dipipet $0,75 \mathrm{ml} ; 1 \mathrm{ml} ; 1,25$ dan 1,5 ml dimasukkan ke dalam labu terukur $25 \mathrm{ml}$ lalu ditambahkan $10 \mathrm{ml}$ larutan DPPH 0,5 mM (konsentrasi 40 ppm) Konsentrasi vitamin C 0,3 ppm, 0,4 ppm, 0,5 ppm dan 0,6 ppm. Kemudian diukur absorbansinya pada panjang gelombnag maksimum, pengukuran dilakukan sebanyak 3 kali pengulangan setelah didiamkan setelah 9 menit.

\section{Penentuan \% Peredaman}

Kemampuan antioksidan diukur sebagai penurunan serapan larutan DPPH (peredaman warna ungu DPPH) akibat adanya penambahan larutan uji. Nilai serapan larutan DPPH sebelum (kontrol) dan sesudah penambahan larutan uji (sampel) tersebut dihitung sebagai persen peredaman.

$$
\begin{gathered}
\text { \% peredaman }=\frac{\left(A_{\text {kontrol }}-A_{\text {sampel }}\right)}{A_{\text {kontrol }}} X 100 \% \\
\text { Keterangan : } \mathrm{A}_{\text {kontrol }} \quad=\text { absorbansi tidak mengandung sampel } \\
\mathrm{A}_{\text {sampel }}=\quad \text { absorbansi mengandung sampel }
\end{gathered}
$$

\section{Penentuan Nilai IC50}

Nilai IC S0 $_{50}$ merupakan bilangan yang menunjukan konsentrasi sampel uji $(\mu \mathrm{g} / \mathrm{ml})$ yang memberikan peredaman DPPH sebesar 50\% (mampu menghambat/meredam proses 
oksidasi sebesar 50\%). Nilai 0\% berarti tidak mempunyai aktivitas antioksidan, sedangkan nilai $100 \%$ berarti peredaman total dan pengujian perlu dilanjukan dengan pengenceran larutan uji untuk melihat batas konsentrasi aktivitasnya. Hasil perhitungan dimasukkan ke dalam persamaan regresi dengan konsentrasi ekstrak $(\mu \mathrm{g} / \mathrm{ml})$ sebagai absis (sumbu X) dan nilai \% peredaman (antioksidan) sebagai ordinatnya (sumbu Y).

Tabel 1. Kategori kekuatan aktivitas antioksidan

\begin{tabular}{ll}
\hline Kategori & Konsentrasi Antioksidan (ppm) \\
\hline Sangat kuat & $<50$ \\
Kuat & $50-100$ \\
Sedang & $101-150$ \\
Lemah & $151-200$ \\
\hline
\end{tabular}

(Sumber : Mardawati et al., 2008).

\section{HASIL DAN PEMBAHASAN}

Nilai $\mathrm{IC}_{50}$ diperoleh berdasarkan persamaan regresi linier yang didapatkan dengan cara memplot konsentrasi larutan uji dan \% peredaman DPPH sebagai parameter aktivitas antioksidan, dimana konsentrasi larutan uji (ppm) sebagai absis dan nilai \% peredaman sebagai kordinat. Hasil persamaan regresi linier dari ekstrak etanol biji kopi arabika dilihat pada table 2 dibawah ini.

Tabel 2. Hasil persamaan regresi linier ekstrak etanol biji kopi arabika

\begin{tabular}{ll}
\hline Larutan Uji & Persamaan regresi \\
\hline Ekstrak etanol biji kopi arabika & $\mathrm{Y}=1,04095 \mathrm{X}+37,064$ \\
& $\mathrm{r}=0,7973$ \\
\hline
\end{tabular}

Hasil analisis nilai $\mathrm{IC}_{50}$ yang diperoleh berdasarkan perhitungan persamaan regresi dapat dilihat pada tabel 3 dan 4 dibawah ini.

Tabel 3. Nilai $\mathrm{IC}_{50}$ ekstrak etanol biji kopi arabika

\begin{tabular}{ll}
\hline Sampel & IC $_{50}(\mathbf{p p m})$ \\
\hline Ekstrak etanol biji kopi arabika & $12,427 \mathrm{ppm}$ \\
\hline
\end{tabular}

Tabel 4. Nilai $\mathrm{IC}_{50}$ vitamin $\mathrm{C}$

\begin{tabular}{ll}
\hline Sampel & IC $_{50}(\mathbf{p p m})$ \\
\hline Vitamin C & $0,273 \mathrm{ppm}$ \\
\hline
\end{tabular}

Pada tabel 3 diatas menunjukan bahwa ekstrak etanol biji kopi arabika memiliki aktivitas antioksidan kategori kuat. 


\section{Hasil Skrining Fitokimia Ekstrak Etanol Biji Kopi Arabika}

Hasil skrining fitokimia ekstrak etanol buah biji kopi arabika menunjukan golongan senyawa-senyawa kimia seperti yang terlihat pada tabel 5 dibawah ini:

Tabel 5. Hasil skrining fitokimia ekstrak etanol buah biji kopi arabika

\begin{tabular}{lll}
\hline Senyawa Metabolit Sekunder & Metode & Hasil \\
\hline Alkaloid & Uji Mayer & + \\
& Uji Bouchardat & + \\
& Uji Dragendrof & + \\
Glikosida & Uji Salkwoski & - \\
Flavonid & Uji Sianidin & + \\
Stroid & Uji Lieberman - Buchardat & + \\
Saponin & Uji busa & + \\
Tanin & Uji warna & + \\
\hline
\end{tabular}

Keterangan :

$(+)$ : mengandung golongan senyawa

$(-)$ : tidak mengandung golongan senyawa

Hasil yang diperoleh pada table 5 diatas menunjukan bahwa ekstrak etanol biji kopi arabika mengandung golongan senyawa flavonoid, saponin, tanin, alkaloid, dan steroid. Hasil pemeriksaan flavonoid terbentuk warna merah kuning atau jingga pada lapisan amil alkohol, pada alkaloid terjadi endapan atau kekeruhan pada dua dari tiga tabung reaksi, pada tanin diperoleh warna hijau kehitaman yang menunjukan adanya tanin dan pada steroid/triterpenoida terbentuk warna biru hijau, hasil pemeriksaan saponin terbentuk busa setinggi 1-3 cm, dan pada steroid/triterpenoida terbentuk warna biru hijau (Depkes, 1995).

Biji kopi arabika memiliki kandungan antioksidan karena kandungan polifenolnya. Polifenol merupakan mikronetrien yang terdapat pada beberapa asupan makanan dan flavonoid merupakan salah satu metabolit sekunder dari senyawa polifenol yang cenderung larut dalam pelarut polar. Polifenol bersifat antioksidan sehingga dapat meredam radikal bebas (Hanindyo, 2014).

\section{KESIMPULAN}

Hasil skrining fitokimia ekstrak biji kopi arabika mengandung golongan senyawa flavonoid, tanin, saponin, alkaloid, dan steroida menunjukkan bahwa senyawa tersebut mempunyai aktivitas antioksidan. Pemeriksaan aktivitas antioksidan dengan menggunakan spektrofotometer visible pada panjang gelombang $517 \mathrm{~nm}$ dengan metode DPPH di peroleh nilai $\mathrm{IC}_{50}$ ekstrak etanol biji kopi arabika 12,427 ppm dan termasuk kedadam katagori sangat kuat, sedangkat vitamin $\mathrm{C} \mathrm{IC}_{50}$ 0,273 ppm termasuk ke dalam kategori sangat kuat. 


\section{DAFTAR PUSTAKA}

Depkes RI. Farmakope Indonesia. Edisi Ketiga. Jakarta: Departemen Kesehatan RI. 1995.

Hanindyo, R. Uji Aktifitas Antioksidan Pada Ekstrak Biji Kopi Robusta (Coffea canephora) Dengan Metoda DPPH. Skripsi. UIN Syarif Hidayatullah. Jakarta. 2014.

Kumalaningsih, S. Antioksidan Alami. Cetakan Pertama. Surabaya: Trubus Agrisarana. 2006.

Mardawati, E., Achyar, C.S, dan Marta, H. Kajian Aktivitas Antioksidan Ekstrak Kulit Manggis (Garcinia mangostana L.) Dalam Rangka Pemanfaatan Limbah Kulit Manggis di Kecamatan Puspahiang Kabupaten Tasikmalaya. Laporan Akhir Peneltian. Bandung: Fakultas Teknologi Industri Pertanian UNPAD. 2008. Halaman 2-3.

Silalahi, J. Makanan Fungsional. Yogyakarta: Penerbit Kanisius. 2006.

Tamat, S.R., Wikanta, T dan Maulina, L.S. Aktivitas Antioksidan dan Toksisitas Senyawa Bioaktif dari Ekstrak Rumput Laut Hijau Ulva Reticulata Forsskal. Jurnal Ilmu Kefarmasian Indonesia, 2007; 5(1).

Winarsi, H. Antioksidan Alami dan Radikal Bebas. Yogyakarta: Penerbit Kanisius. 2007. 